\title{
PENGARUH PELATIHAN DAN MOTIVASI TERHADAP KINERJA KARYAWANDI MAXONE HOTEL SEMINYAK - BALI
}

\author{
Bagus Putu Ekadharma Susila ${ }^{1}$, Ni Putu Oka Ariantini ${ }^{2}$ \\ Akademi Komunitas Manajemen Perhotelan Indonesia \\ Badung, Indonesia \\ ganesha0405@yahoo.co.id ${ }^{1}$, okaariantini100@gmail.com ${ }^{2}$
}

\begin{abstract}
Abstrak
Penelitian ini bertujuan untuk mengetahui pengaruh Pelatihan dan Motivasi terhadap Kinerja Karyawan di Maxone Hotel. Seminyak- Bali. Kuesioner yang disebarkan kepada 93 responden merupakan seluruh anggota populasi. Penelitian ini, mempergunakan teknik analisis regresi dengan pengujian hipotesis menggunakan Uji $T$ dan Uji F. Hasil Uji $T$ menunjukan bahwa Pelatihan (X1) berpengaruh positif dan signifikan terhadap Kinerja Karyawan (Y), dimana koefisien regresi $X 1(b 1)$ thitung $=8.614>$ ttabel $(0,05: 34)=1.6909$ dan sig $t=0,000(p<0,05)$ menunjukkan bahwa Ho ditolak dan menerima $\mathrm{Ha}$. Sedangkan pengaruh Motivasi(X2) terhadap Kinerja Karyawan $(\mathrm{Y})$ adalah $\mathrm{X} 2(\mathrm{~b} 2)$ thitung $=9.254>\operatorname{ttabel}(0,05: 34)=1.609$ dan sig $\mathrm{t}=0,000$ $(p<0,05)$, yang berarti bahwa Motivasi $(X 2)$ berpengaruh positif dan signifikan terhadap kinerja karyawan $(\mathrm{Y})$. Sehingga $\mathrm{Ho}=$ ditolak dan menerima hipotesis alternative $(\mathrm{Ha})$. Uji $\mathrm{F}$ menunjukan bahwa Pelatihan (X1) dan Motivasi $(\mathrm{X} 2)$ terhadap Kinerja Karyawan $(\mathrm{Y})$ dimana $\mathrm{F}$ hitung = $422 \cdot 319>$ Ftabel $=3.28$ dan sig $F=0,000(p<0,05)$. Sehingga dapat disimpulan bahwa HO ditolak dan menerima Ha serta berpengaruh positif dan signifikan.
\end{abstract}

Kata kunci : Pelatihan, Motivasi, Kinerja Karyawan

\section{PENDAHULUAN}

Bali sebagai salah satu daerah tujuan wisata di Indonesia memiliki berbagai ragam budaya dan adat istiadat yang sampai sekarang masih terjaga kelestariannya. Serta dengan didukung oleh sifat ramah tamah yang dimiliki oleh penduduk setempat menjadikan tamu merasa nyaman dan aman selama berlibur di Bali. Sehingga Bali mendapatkan berbagai macam julukan seperti Island of the Gods, Island of thousand tamples, Bali is my second home dan lain sebagainya. Pembangunan sarana dan prasarana serta akomodasi pariwisata dari tahun ketahun, terus mengalami peningkatan seiring dengan meningkatnya jumlah tamu yang datang ke Seminyak. Hal ini tidak terlepas dari peranan aktif masyarakat dan Pemerintah Daerah didalam mengembangkan serta mendukung program pariwisata yang ada di daerah Seminyak. Pembangunan tersebut diantaranya, seperti: perluasan dan perbaikan jalan, agen biro perjalanan dengan pemandu wisata, pembangunan hotel/villa, restoran, pub dan discotique.

Dewasa ini pembangunan hotel banyak dibangun di Seminyak. Hal ini menyebabkan persaingan yang semakin ketat dalam usaha untuk mendapatkan tamu, belum lagi dengan tamu yang semakin selektif di dalam memilih tempat untuk menginap selama berada di Bali. Untuk itu perusahaan harus mempersiapkan diri dalam berbagai bentuk strategi di dalam mempertahankan ataupun 
meningkatkan jumlah kunjungan tamu yang datang.

Maxone Hotel adalah salah satu hotel yang ada di daerah Seminyak. Bentuk usaha manajemen di dalam mempertahankan ataupun meningkatkan jumlah kunjungan tamu adalah dengan memberikan pelayanan yang terbaik kepada setiap tamu yang datang ke Maxone Hotel Seminyak. Karyawan akan mampu memberikan pelayanan dengan baik, bila memiliki kinerja yang tinggi terhadap perusahaan. Peningkatan kinerja karyawan dapat dilakukan dengan beberapa cara, diantaranya dengan memberikan pelatihan dan motivasi.

Tamu yang datang ke Maxone Hotel, merupakan wujud nyata dari usaha perusahaan dan kinerja karyawan di dalam bekerja. Untuk dapat meningkatkan jumlah kunjungan tamu, sesuai dengan target perusahaan, maka pihak manajemen Maxone Hotel Seminyak mengadakan pelatihanpelatiahn untuk meningkatkan kualitas pelayanan. Pelatihan ini bertujuan agar karyawan memahami peraturan tata tertib yang ada di departemennya masing-masing serta pentingnya bekerjasama diantara teman sekerja maupun diantara departemen yang ada. Karyawan yang mengikuti pelatihan diharapkan mendapatkan pengetahuan, keterampilan dan efesiensi kerja yang lebih baik. Pengembangan wawasan berfikir dan kualitas pimpinanpun perlu ditingkatkan, sehingga pimpinan untuk masing-masing departemen dapat melaksanakan fungsi manajemennya dengan lebih baik.

Selain pelatihan, motivasi berpengaruh terhadap kinerja karyawan. Motivasi yang diberikan perusahaan kepada karyawan Maxone Hotel Seminyak, seperti: gaji pokok, bonus atau uang servis, tunjangan kesehatan, tunjangan hari raya dan kesempatan untuk berkarir. Manajemen berharap agar motivasi yang diberikan akan berpengaruh positif terhadap kepribadian karyawan seperti adanya keinginan untuk mengembangkan kemampuan dan karir, keinginan untuk melakukan yang terbaik serta bertanggungjawab terhadap tugas dan kewajiban terhadap pekerjaannya.

Manajemen dalam usahanya untuk memenuhi target jumlah kunjungan tamu ke Maxone Hotel, diantaranya dengan melakukan pengelolaan sumber daya manusia. Pengelolaan sumber daya manusia bertujuan untuk meningkatkan kinerja karyawan diantaranya dengan memberikan palatihan dan motivasi. Oleh karena itu penulis tertarik untuk melakukan penelitian pengaruh pelatihan dan motivasi terhadap kinerja karyawan di Maxone Hotel Seminyak.

\section{Rumusan Masalah}

Berdasarkan uraian dalam latar belakang masalah, maka dapat dirumuskan beberapa permasalahan terkait dengan penelitian yang dilakukan di Maxone Hotel sebagai berikut:

1. Apakah pelatihan berpengaruh terhadap kinerja karyawan di Maxone Hotel Seminyak-Bali?

2. Apakah motivasi berpengaruh terhadap kinerja karyawan di Maxone Hotel Seminyak-Bali?

3. Apakah pelatihan dan motivasi berpengaruh terhadap kinerja karyawan di Maxone Hotel Seminyak-Bali?

Pelatihan direncanakan dan dirancang oleh manajemen perusahaan dalam usaha mengembangkan dan meningkatkan sumberdaya yang ada di dalam perusahaan tersebut. Pelatihan yang berkelanjutan membuat karyawan memiliki cara kerja yang lebih baik. Dengan pelatihan yang tepat diharapkan karyawan dapat meningkatkan 
pengetahuan serta keterampilan dalam menghadapi permasalahan yang muncul dalam pekerjaanya.

Pelatihan menurut Dessler (2015) adalah proses mengajarkan karyawan baru atau yang ada sekarang, tentang ketrampilan dasar yang mereka butuhkan untuk menjalankan pekerjaan mereka. Pelatihan merupakan salah satu usaha dalam meningkatkan mutu sumber daya manusia dalam dunia kerja. Karyawan, baik yang baru ataupun yang sudah bekerja perlu mengikuti pelatihan karena adanya tuntutan pekerjaan yang dapat berubah akibat perubahan lingkungan kerja, strategi dan lain sebagainya.

Ivancevich dalam Marwansyah (2014), pelatihan adalah proses sistematis untuk mengubah perilaku karyawan, yang diarahkan untuk mencapai tujuan-tujuan organisasi. Pelatihan terkait dengan keterampilan dan kemampuan pekerjaan saat ini. Orientasinya adalah saat ini membantu karyawan menguasai keterampilan dan kemampuan spesifik agar berhasil dalam pekerjaan.

Sebelum memberikan pelatihan kepada karyawan, maka manajemen harus merumuskan tujuan dari pelatihan, waktu pelatihan, tingkat jabatan karyawan serta manfaat dari pelatihan untuk karyawan yang nantinya akan bermanfaat dalam mengerjakan pekerjaannya di dalam mencapai tujuan perusahaan.

Simamora (2012), ada beberapa tujuan utama dari pelatihan adalah:

1. Memperbaiki kinerja

Sasaran utamanya adalah karyawan yang belum mencapai standar pekerjaan yang diharapkan dibidang pekerjaanya masingmasing, termasuk didalamnya adalah calon karyawan dan karyawan yang baru dipromosikan.
2. Memutakhirkan keahlian para karyawan sejalan dengan kemajuan teknologi

Penggunaan teknologi baru harus selaras dengan peningkatan sumber daya manusia. Karyawan melalui pelatihan dipastikan dapat secara efektif menggunakan teknologi baru untuk diintegrasikan ke dalam pekerjaanya.

3. Membantu memecahkan permasalahan operasional

Pelatihan sangat membantu karyawan didalam memecahkan masalah dalam pekerjaan dengan lebih baik.

4. Persiapan untuk promosi

Pelatihan bertujuan untuk mempersiapkan promosi karyawan kejenjang karir yang lebih tinggi.

5. Mengorientasikan karyawan terhadap organisasi

Bagi karyawan yang baru diterima bekerja, sangat perlu diberikan pelatihan tentang arah dan tujuan perusahaan beserta sistem kerja. Sedangkan bagi karyawan yang sudah lama bekerja, pelatihan ini bersifat penyegaran (refreshment), agar setiap karyawan mempunyai sudut pandang dan semangat kerja yang sama didalam mencapai tujuan perusahaan.

6. Memenuhi kebutuhan-kebutuhan pertumbuhan pribadi

Pelatihan dapat memainkan peranan yang membuahkan efektifitas organisasi yang lebih besar dan meningkatkan pertumbuhan pribadi bagi semua karyawan.

Pelatihan yang telah diberikan kepada karyawan diharapkan akan meningkatkan kinerja karyawan, sehingga mereka menjadi lebih produktif dan dapat diberikan tanggung jawab yang lebih besar didalam melaksanakan pekerjaan. Dalam hal ini perusahaan atau manajemen harus mempunyai 
cara, alat ukur atau indikator-indikator sebagai acuan bahwa pelatihan tersebut memang bermanfaat bagi karyawan dan perusahaan. Menurut Kaswan (2012) mengungkapkan beberapa indikator dalam pelatihan, sebagai berikut: (1) Identifikasi, (2) Motivasi, (3) Lingkungan pembelajaran,

Penerapan, (5) Metode dan (6) Hasil

Sardiman (2014), menyebutkan motivasi dapat diartikan sebagai daya upaya yang mendorong seseorang untuk melakukan sesuatu. Motivasi merupakan kondisi internal sebagai daya penggerak dan berada di dalam subjek untuk melakukan aktifitas dalam pencapaian tujuan.

Faktor-faktor motivasi yang mempengaruhi karyawan didalam melakukan pekerjaannya berdasarkan pendapat dari Sutrisno (2012)yaitu:

1. Faktor Internal

Faktor internal terdiri dari :

a. Keinginan untuk hidup

Faktor ini merupakan faktor yang paling mendasar yang ada pada setiap mahluk hidup yang ada di bumi ini. Manusia didalam mempertahankan kehidupannya harus bekerja untuk mendapatkan makanan.

b. Keinginan untuk dapat memiliki

Faktor keinginan untuk memiliki sesuatu yang tidak dimiliki dan keinginan untuk memiliki sesuatu yang lebih banyak membuat seseorang harus bekerja lebih giat.

c. Keinginan untuk memperoleh penghargaan

Bahwa setiap orang selalu ingin dihargai, apapun tingkat pendidikan, pekerjaannya dan tingkat sosialnya, mereka selalu ingin dihargai.

2. Faktor Eksternal

Faktor eksternal terdiri dari:

a. Kondisi/lingkungan pekerjaan
Kondisi/lingkungan pekerjaan dimana karyawan sedang bekerja sangat mempengaruhi aktifitas karyawan, serta didukung oleh sarana dan prasarana yang memadai.

b. Kompensasi yang memadai

Kompensasi berupa uang yang memadai membuat karyawan bekerja dengan tenang, sehingga karyawan dapat bekerja dengan lebih baik. Konpensasi yang kurang atau tidak memenuhi kebutuhannya, membuat karyawan menjadi tidak bersemangat bekerja.

c. Supervisi yang baik

Supervisor/pimpinan mempunyai tugas untuk melaksanakan tugas pengawasan dengan baik. Sehingga di dalam pembagian tugas, karyawan merasa adil. Pimpinan selalu mempunyai waktu membimbing dan mengarahkan bawahannya dalam bekerja.

d. Adanya jaminan pekerjaan

Adanya jaminan pekerjaan berupa jaminan masa depan, karir, pengembangan potensi diri dan peningkatan pendapatan. Apabila karyawan merasa bahwa hal tersebut didapatkan di perusahaan di mana sedang bekerja, maka karyawan akan bekerja dengan baik (Setiadi, 2008).

e. Status dan kedudukan

Status dan kedudukan yang lebih baik merupakan idaman setiap karyawan. Karena kedudukan yang lebih tinggi akan diikuti oleh penghasilan yang lebih tinggi pula.

f. Peraturan yang fleksibel

Peraturan perusahaan dibuat untuk mempertegas hubungan karyawan dengan perusahaan. Di dalam peraturan tersebut akan diatur secara tegas dan terperinci mengenai hak dan kewajiban masing-masing pihak. Dimana 
kedua belah pihak haruslah sama-sama dilindungi dan diuntungkan.

Kinerja berasal dari kata job performance atau actual performance yang berarti prestasi kerja atau prestasi sesungguhnya yang dicapai oleh seseorang, di dalam melaksanakan fungsinya sesuai dengan tugas dan tanggung jawab yang diberikan kepadanya.

Kinerja adalah kualitas dan kuantitas serta waktu yang digunakan dalam menjalankan tugasnya. Kualitas adalah hasil yang dapat dihitung sejauh mana seseorang dapat mencapai tujuan yang telah ditetapkan (Sutrisno, 2012).

Keith Davisdalam Mangkunegara (2008) dirumuskan bahwa faktor-faktor yang dapat mempengaruhi kinerja adalah :

Human Performance $=$ Ability + Motivation (Knowledge + Skill) + (Attitude + Situation)

Kemampuan (Ability) karyawan sangat ditentukan oleh pengetahuan dan keahlian yang dimilikinya. Sedangkan motivasi (motivation) terbentuk dari sikap dan prilaku karyawan di dalam menghadapi situasi kerja.
Mangkunegara

(2008), menyatakan bahwa indikator-indikator kinerja adalah :

1. Kualitas Seberapa baik seorang karyawan mengerjakan pekerjaanya

2. Kuantitas Jumlah pekerjaan yang dapat diselesaikan dengan baik

3. Pelaksanaan tugas

Seberapa jauh karyawan mampu melaksanakan pekerjaanya dengan akurat atau tanpa ada kesalahan.

4. Tanggung jawab

Kesadaran karyawan akan kewajiban yang harus dilaksanakan

Pelatihan merupakan proses peningkatan kemampuan karyawan baik kemampuan teknis maupun kemampuan berfikir didalam mereka menyelesaikan pekerjaan. Pelatihan ini akan berdaya guna jika adanya motivasi yang baik diantara karyawan dan manajemen sehingga menghasilkan kinerja atau prestasi kerja yang tinggi. Untuk lebih memperjelas hubungan antara variabel dalam penelitian ini maka dibuat kerangka konseptual atau kerangka berfikir seperti pada tabel di bawah ini:

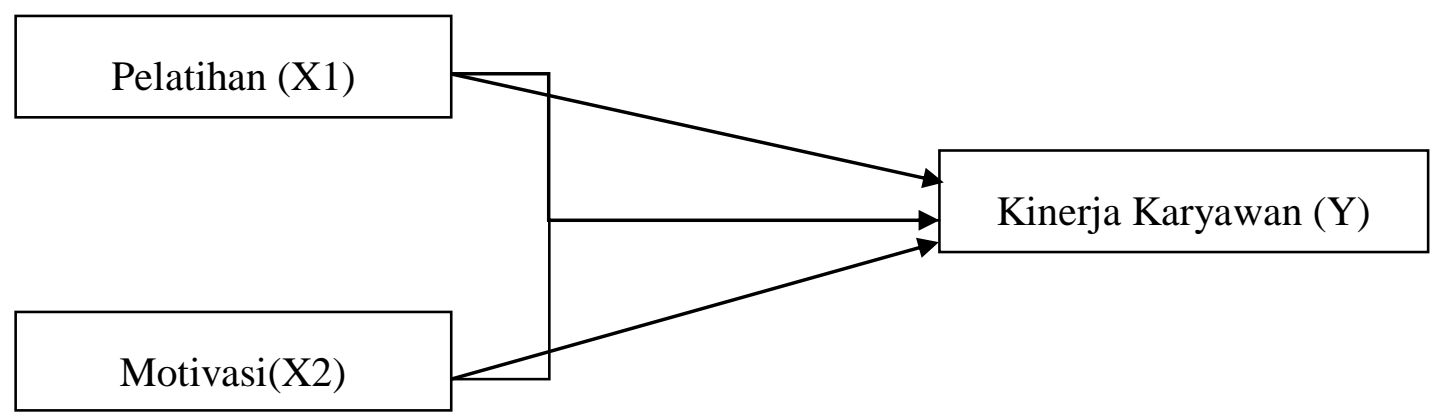

GAMBAR 2.1. Kerangka pemikiran pelatihan dan motivasi Terhadap kinerja karyawan Maxone Hotel Seminyak - Bali

Berdasarkan uraian rumusan masalah dan pokok permasalahan yang diperkuat oleh landasan teori dan penelitian sebelumnya, maka dapat ditarik beberapa hipotesis sebagai berikut: 
1. Terdapat pengaruh positif antara pelatihan terhadap kinerja karyawan Maxone Hotel Seminyak - Bali

2. Terdapat pengaruh positif antara motivasi terhadap kinerja karyawan Maxone Hotel Seminyak - Bali

3. Terdapat pengaruh positif antara pelatihan dan motivasi terhadap kinerja karyawan Maxone Hotel, Seminyak - Bali

\section{METODE PENELITIAN}

Variabel-variabel yang digunakan dalam penelitian ini adalah sebagai berikut: Variabel Bebas (X), Pelatihan (X1) dan Motivasi (X2) merupakan variabel bebas dalam penelitian. Kemudian Variabel Terikat (Y) adalah Kinerja karyawan sebagai variabel terikat dalam penelitian ini.

Tabel 3.1

Variabel Operasional Pelatihan, Indikator dan Item Pertanyaan

\begin{tabular}{|c|c|c|c|}
\hline NO & $\begin{array}{c}\text { Variabel } \\
\text { Operasion } \\
\text { al }\end{array}$ & Indikator & Item Pertanyaan \\
\hline 1 & $\begin{array}{l}\text { Pelatihan } \\
\text { (X1) }\end{array}$ & $\begin{array}{ll}\text { 1. } & \text { Metode } \\
\text { 2. Identifikasi } \\
\text { 3. Motivasi } \\
\text { 4. Lingkungan } \\
\text { 5. Pembelajaran } \\
\text { 6. Penerapan } \\
\text { 7. Hasil } \\
\end{array}$ & $\begin{array}{l}\text { 1. Teknik pengajaran yang menarik } \\
\text { 2. Peserta pelatihan } \\
\text { 3. Berdaya guna terhadap pekerjaan } \\
\text { 4. Tempat pelatihan yang memadai } \\
\text { 5. Pemahaman pelatihan } \\
\text { 6. Penerapan dalam tugas karyawan } \\
\text { 7. Peningkatan efisiensi kerja }\end{array}$ \\
\hline 2 & $\begin{array}{l}\text { Motivasi } \\
\text { (X2) }\end{array}$ & $\begin{array}{l}\text { Motivator Ekstrinsik } \\
\text { 1. Upah } \\
\text { 2. Kondisi kerja } \\
\text { 3. Keamanan kerja } \\
\text { 4. Status } \\
\text { 5. Prosedur } \\
\text { perusahaan } \\
\text { 6. Mutu penyeliaan } \\
\text { 7. Hubungan kerja } \\
\text { Motivator Intrinsik } \\
\text { 8. Pencapaian } \\
\text { prestasi } \\
\text { 9. Pengakuan } \\
\text { 10. Tanggung jawab } \\
\text { 11. Kemajuan } \\
\text { 12. Pekerjaan } \\
\text { 13. Pengembang } \\
\text { karir }\end{array}$ & $\begin{array}{l}\text { 1. Upah yang diterima } \\
\text { 2. Kondisi kerja yang nyaman } \\
\text { 3. Rasa aman dalam bekerja } \\
\text { 4. Status karyawan yang jelas } \\
\text { 5. Prosedur perusahaan yang fleksible } \\
\text { 6. Perhatian tehadap karyawan } \\
\text { 7. Hubungan karyawan yang harmonis } \\
\text { 8. Keinginan untuk berprestasi } \\
\text { 9. Adanya pujian dari atasan terhadap } \\
\text { karyawan } \\
\text { 10. Kesadaran akan tugas dan tanggung } \\
\text { jawab } \\
\text { 11. Peningkatan keterampilan dan } \\
\text { pengetahuan } \\
\text { 12. Kesadaran untuk melakukan } \\
\text { pekerjaanya } \\
\text { 13. Kesempatan yang sama dalam berkarir }\end{array}$ \\
\hline 3 & $\begin{array}{c}\text { Kinerja } \\
\text { Karyawan } \\
(\mathrm{Y})\end{array}$ & $\begin{array}{l}\text { 1. Kualitas } \\
\text { 2. Kuantitas } \\
\text { 3. Pelaksanaan } \\
\text { tugas } \\
\text { 4. Tanggung jawab }\end{array}$ & $\begin{array}{l}\text { 1. Kemampuan dalam menyelesaikan } \\
\text { pekerjaan } \\
\text { 2. Jumlah pekerjaan yang dapat } \\
\text { diselesaikan } \\
\text { 3. Kemampuan dalam melaksanakan } \\
\text { pekerjaan } \\
\text { 4. Sadar dan bertanggung jawab di dalam } \\
\text { melakukan pekerjaan }\end{array}$ \\
\hline
\end{tabular}

Sumber: Kaswan (2012), Frederick Herzberg (Robbins, 2007), Mangkunegara (2008) 
Jenis Data yang digunakan adalah Data Kuantitatif berupa angka-angka yang dapat dihitung dan diolah, seperti jumlah karyawan dan tingkat kunjungan tamu. Serta Data Kualitatif dalam bentuk informasi, seperti sejarah berdirinya restoran, fasilitas hotel dan struktur organisasi.

Sumber data primer diperoleh dan dikumpulkan secara langsung di tempat penelitian kepada karyawan melalui wawancara dan kuesioner. Dan data sekunder diperoleh sudah dalam bentuk jadi, seperti: sejarah hotel dan struktur organisasi.

Prosedur pengumpulan data yang digunakan adalah: Wawancara, Penyebaran kuesioner diukur dengan menggunakan skala Likert 5 poin, dan dokumentasi dengan mengumpulkan data dari dokumen serta laporanlaporan yang tentunya sangat erat dengan penelitian ini, seperti sejarah berdirinya hotel, struktur organisasi dan jumlah karyawan.

Menurut Arikunto (2013), menyatakan apabila subjek kurang dari 100, maka lebih baik subjek diambil semua, sehingga penelitian merupakan populasi atau sensus. Sedangkan apabila subjek di atas 100, maka dapat diambil antara 10\%, 20\% atau 50\% sebagai sampel. Berdasarkan pendapat Arikunto maka populasi dalam penelitian ini adalah seluruh karyawan Maxone Hotel yang berjumlah 37 orang.

Analisis statistik deskriptif memerlukan data yang aktual dan akurat mengenai fakta-fakta serta hubungan antara fenomena yang diselidiki atau diteliti, seperti usia, jenis kelamin, masa kerja dan tingkat pendidikan.

Instrumen penelitian dikatakan valid apabila mampu mengukur apa yang harus diukur dan mengungkapkan data dari variabel-variabel yang diteliti secara tetap. Menurut Sunyoto (2013) pengujian validitas dilakukan dengan kreteria sebagai berikut:

a. Jika $r$ hitung $>r$ tabel, maka pertanyaan dinyatakan valid

b. Jika $r$ hitung $<r$ tabel, maka pertanyaan dinyatakan tidak valid

Dan bila harga korelasi positif dan $r \geq$ 0.3 maka butir instrument tersebut dinyatakan valid atau memiliki validitas konstruk yang baik. Proses pengujian validitas pada penelitian ini mempergunakan alat bantu SPSS versi 23.

Uji Reliabilitas Instrumen Penelitian untuk mengukur suatu kuesioner yang merupakan indikator dari variabel atau konstruk (Sunyoto, 2013). Suatu konstruk dinyatakan reliabel/konsisten jika nilai korelasi > 0,6 . Analisis yang digunakan untuk mengetahui besarnya derajat atau kekuatan hubungan antara satu variabel bebas, apabila variabel bebas yang lain dianggap konstan. Koefisien korelasi parsial antara $\mathrm{Y}$ dan $\mathrm{X}_{1}$ apabila $\mathrm{X}_{2}$ konstant

$$
r y 12=\frac{r Y_{1}-r Y_{2} \cdot r_{1.2}}{\sqrt{\left(1-r Y_{2}^{2}\right)\left(1-r_{1.2}\right)^{2}}}
$$

Koefisien korelasi parsial antara Y dan $\mathrm{X}_{2}$ apabila $\mathrm{X}_{1}$ konstanta

$$
\text { ry } 12=\frac{r Y_{2}-r Y_{1} \cdot r_{1.2}}{\sqrt{\left(1-r Y_{1}^{2}\right)\left(1-r_{1.2}^{2}\right)}}
$$

Keterangan :

ry1 $=$ Koefisien korelasi antara variabel terikat Kinerja Karyawan ( $\mathrm{Y}$ ) dengan variabel bebas Pelatihan (X1)

ry2 $=$ Koefisien korelasi antara variabel terikat Kinerja Karyawan (Y) dengan variabel bebas Motivasi (X2)

$r 12=$ Koefisien korelasi antara variabel bebas Pelatihan (X1) dengan 
variabel bebas Motivasi (X2)

ry12= Koefisien korelasi antara variabel terikat Kinerja Karyawan ( $\mathrm{Y}$ ) dengan variabel bebas Pelatihan (X1) konstan

ry21 = Koefisien korelasi antara variabel terikat Kinerja Karyawan (Y) dengan variabel bebas Motivasi (X2), dengan menganggap variabel bebas Pelatihan (X1) konstan.

Analisis Korelasi Berganda digunakan untuk mengetahui besarnya derajat atau kekuatan hubungan antara variabel-variabel X1 (Pelatihan), $\mathrm{X} 2$ (Motivasi) dan Y (Kinerja Karyawan). adalah:

Rumus analisis korelasi berganda

$$
\mathrm{R}^{2}=\frac{\mathrm{JK}}{\sum \mathrm{Y}^{2}}
$$

Keterangan:

$R 2=$ Koefisien Korelasi Ganda $J K($ reg $)=$ Jumlah Kuadrat
$\Sigma Y^{2}=$ Jumlah Kuadrat Total Korelasi

Untuk mencari

$J K_{(r e g)}$ mempergunakan rumus :

$J K_{(r e g)}=b_{1} \sum X_{1} \mathbf{Y}+b_{2} \sum X_{2} \mathbf{Y}$

Dimana :

$$
\begin{aligned}
& \sum X_{1} Y=\sum X_{1} Y-\frac{\left(\sum X_{1}\right)\left(\sum Y\right)}{n} \\
& \sum X_{2} Y=\sum X_{2} Y-\frac{\left(\sum X_{2}\right)\left(\sum Y\right)}{n}
\end{aligned}
$$

Untuk mencari $\quad \sum Y^{2}$ menggunakan rumus sebagai berikut:

$$
\sum Y^{2}=\sum Y^{2-\frac{(\Sigma Y)^{2}}{n}}
$$

Interpretasi terhadap kuatnya hubungan korelasi berpedoman pada pendapat dari Sugiyono (2014) sebagai berikut

Tabel 3.3

Pedoman Interpretasi Koefisien Korelasi

\begin{tabular}{|c|c|}
\hline Interval Koefisien & Tingkat Hubungan \\
\hline $0,00-0,199$ & Sangat rendah \\
$0,20-0,399$ & Rendah \\
$0,40-0,599$ & Sedang \\
$0,60-0,799$ & Kuat \\
$0,80-1,000$ & Sangat kuat \\
\hline
\end{tabular}

Sumber: Sugiyono (2014)

Analisis Regresi Berganda ini digunakan untuk mengetahui besarnya pengaruh variabel bebas $(\mathrm{X} 1=$ Pelatihan dan $\mathrm{X} 2=$ Motivasi) terhadap variabel terikat $(\mathrm{Y}=$ Kinerja). Rumus analisis regresi berganda menurut Sunyoto (2013) adalah:

$$
Y=a+b_{1} x_{1}+b_{2} x_{2}
$$

Keterangan :

$\mathrm{Y}=$ Variabel terikat (Kinerja karyawan )

$\mathrm{a}=$ Konstanta

$b 1=$ Koefisien regresi dari pelatihan

b2 = Koefisien regresi dari motivasi

$\mathrm{X} 1=$ Variabel bebas ( Pelatihan )

X2 $=$ Variabel bebas ( Motivasi ) 
Model regresi berganda dapat dikatakan baik, jika model tersebut memenuhi beberapa asumsi, yang kemudian disebut asumsi klasik. Proses uji asumsi klasik dilakukan dengan langkah-langkah yang sama dengan proses uji regresi.

Uji asumsi klasik terdiri dari: (1) Uji Normalitas, dipergunakan untuk menguji apakah populasi data berdistribusi normal atau tidak. Pengujian normalitas dilakukan terhadap masing-masing variabel bebas $\mathrm{X} 1$ (Pelatihan), $\mathrm{X} 2$ (Motivasi) dan variabel terikat $Y$ (Kinerja Karyawan).

Seluruh variabel tersebut diuji dengan menggunakan uji One Sample Kolmogorof-Smirnov yang telah diprogram dalam program SPSS (Statistic Package for Social Science) versi 23 dengan taraf tertentu yang dipergunakan sebagai dasar untuk mengambil keputusan apakah menerima ataupun menolak suatu distribusi data. Data berdistribusi normal jika signifikasi lebih $\geq 0,05$ ( Sujarweni, 2014).

Uji Multikolinearitas, dipergunakan untuk menunjukan adanya hubungan linier yang sempurna diantara variabelvariabel bebas dalam model regresi. Idealnya variabel-variabel bebas dari persamaan regresi tidak memiliki korelasi satu dengan lainnya. Jika terjadi korelasi antar variabel bebas maka tingkat korelasi tersebut haruslah rendah, agar tidak terjadi masalah akibat multikolinearitas. Menurut Subiyanto (2000), menyatakan konsekuensi yang ditimbulkan dari adanya multikolinearitas adalah: Apabila terdapat kolinearitas sempurna diantara variabel $x$, maka koefisien regresi menjadi tak tertentu, dengan tingkat kesalahan standar yang tak terhingga.

Jika terdapat kolinearitas dengan tingkat yang tinggi tetapi tidak sempurna, maka penafsiran koefisien regresi adalah mungkin, tetapi kesalahan standarnya cenderung besar sehingga nilai populasi dari koefisien tidak dapat ditafsirkan dengan tepat. Uji Multikolinearitas juga dapat dilakukan dengan melihat tolerance value dan Variance Inflation Factor (VIF). Jika nilai VIF lebih besar dari 10 atau tolerance value dibawah 0,1 maka terjadi multikolinearitas.

Uji Heteroskedastistisitas, dilakukan dengan melihat grafik scatterplot antara stresid dengan zpred dimana sumbu $X$ adalah residual dan sumbu $Y$ adalah teks yang diprediksi.

Koefisien determinasi berganda bertujuan untuk melihat persentase pengaruh variabel $\mathrm{X} 1$ (Pelatihan), $\mathrm{X} 2$ (Motivasi), terhadap $Y$ (Kinerja Karyawan). Rumus koefisien determinasi berganda yang digunakan adalah:

$K d=R^{2} \times 100 \%$

Keteranagan:

$\mathrm{Kd}=$ Koefisien determinasi

$\mathrm{R}^{2}=$ Kuadrat dari koefisien korelasi

Uji hipotesis akan mengarahkan pada kesimpulan untuk menolak atau menerima hipotesis. Pengujian terhadap hipotesis dalam penulisan ini mempergunakan cara sebagai berikut:

1. Uji T (Uji Signifikan Parsial)

Uji $\mathrm{T}$ dipergunakan untuk membuktikan " apakah pengaruh pelatihan dan motivasi secara parsial terhadap kinerja karyawan di Maxone Hotel " diperoleh secara benar atau secara kebetulan saja.

Adapun langkah-langkah dalam Uji T adalah sebagai berikut:

a. Menentukan hipotesis nol (Ho) dan hipotesis alternative $(\mathrm{Ha})$ Jika Ho : $b \leq 0$, berarti variabel bebas tidak berpengaruh positif secara parsial terhadap variabel terikat.

Jika Ho : b $>0$, berarti variabel bebas berpengaruh positif secara parsial terhadap variabel terikat 
b. Menentukan level signifikan a dalam penelitian ini adalah 5\%

c. Test statistik dengan rumus :

$$
T=\frac{b-\beta}{S b}
$$

dihitung

$$
\begin{gathered}
\text { Keterangan : } \\
\mathrm{T}
\end{gathered}
$$

$$
\mathrm{B}=
$$

Koefisien regresi dari variabel bebas

$$
\mathrm{B}=\text { Beta }
$$$$
\mathrm{Sb}=
$$

Tingkat kesalahan koefisien regresi

d. Membandingkan antara $\mathrm{T}$ hitung dengan $\mathrm{T}$ tabel

Apabila $\mathrm{T}$ hitung $>\mathrm{T}$ tabel maka Ho ditolak dan menerima hipotesis alternative (Ha). Ini berarti terdapat pengaruh antara variabel bebas dengan variabel terikat.

Apabila $T$ hitung $\leq T$ tabel maka Ho diterima dan menolak hipotesis alternative $(\mathrm{Ha})$. Ini berarti tidak terdapat pengaruh antara variabel bebas dengan variabel terikat.

Adapun uji signifikan adalah:

- Bila sig $t(p)>0,05(\alpha)$ artinya tidak signifikan

- Bila sig $t(p)<0,05(\alpha)$ artinya signifikan

e. Kesimpulan Merupakan keputusan dari analisis yang dilakukan.

2. Uji F (Uji Signifikan Simultan)

Uji $F$ dilakukan untuk menguji apakah pengaruh pelatihan dan motivasi secara simultan terhadap kinerja karyawan di Maxone Hotel. Adapun langkah-langkah dalam Uji $T$ adalah sebagai berikut:

a. Menentukan hipotesisnol (Ho) dan hipotesis alternative $(\mathrm{Ha})$.

Ho : b1 = 0; b2=0 maka, berarti variabel bebas tidak berpengaruh positif secara simultan terhadap variabel terikat

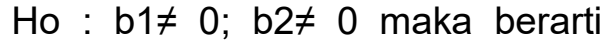
variabel bebas berpengaruh positif secara simultan terhadap variabel terikat

b. Menentukan taraf nyata $=5 \%$ dan derajat bebas (df) $=(k-1) ;(n-k)$ untuk menentukan batas daerah penerimaan dan penolakan hipotesis

c. Signifikan koefisien korelasi berganda dihitung dengan rumus:

$$
\begin{gathered}
\text { Ftest }=\frac{R^{2} / K}{\left(1-R^{2}\right) /(n-K-1)} \\
\text { Keterangan: } \\
\mathrm{R}^{2}=\text { Koefisien korelasi } \\
\text { berganda yang telah ditentukan } \\
N=\text { Jumlah sampel } \\
\mathrm{K}=\text { Jumlah variabel bebas }
\end{gathered}
$$

d. Membandingkan Fhitung dengan Ftabel

Apabila $F$ hitung $>F$ tabel maka Ho ditolak dan menerima hipotesis alternative (Ha). Ini berarti semua variabel bebas berpengaruh terhadap nilai variabel terikat.

Apabila $F$ hitung $\leq F$ tabel maka, Ho diterima dan menolak hipotesis alternative (Ha). Ini berarti semua variabel bebas tidak berpengaruh terhadap nilai variabel terikat.

\section{HASIL DAN PEMBAHASAN}

Maxone Hotel Seminyak Bali dibawah naungan MPHG (Milestone Pasifik Hotel Groups) manajemen merupakan hotel bintang 3 yang bergerak dibidang jasa pelayanan akomodasi yang berlokasi di :

Alamat: Jalan Cendrawasih No. 28 Petitenget Kuta Utara Bali.

Telepon: +62 3618974111.

Website: www.maxonehotels.com.

Dengan mengusung konsep design hotel with the feeling atau hotel budget dengan memunculkan tema budaya lokal namun tetap terkesan modern. Dibangun pada tahun 2013 dan mulai dapat beroperasi atau soft opening tanggal 11 juli 2015. Sebagai bagian dari chain hotel ada \pm 26 
Maxone di seluruh Indonesia. Di Bali sendiri ada 3 Maxone yaitu di Jimbaran, Legian dan Seminyak dan satu hotel bintang 4 yang bernama Zia hotel yang juga ada di Petitenget. MPHG sendiri membawahi 3 katagori hotel yaitu Night And Day Hotel (bintang 2), Maxone Hotel (bintang 3) dan Zia Hotel (bintang 4).

Sama halnya dengan hotel-hotel yang lainnya Maxone Hotel Seminyak
Bali memiliki fasilitas dan pelayanan yang sangat mendukung untuk tamutamu yang menginap baik lokal maupun manca negara.

\section{Hasil Uji Validitas Dan Reliabilitas Dari Instrumen Penelitian}

Adapun hasil uji validitas dan reliabilitas dari instrumen penelitian pada obyek yang diteliti, dapat diuraikan pada tabel 4.1:

Tabel 4.1

Hasil Uji Validitas dan Reliabilitas Instrumen Penelitian

\begin{tabular}{|c|c|c|c|c|c|}
\hline NO & VARIABEL & $\begin{array}{c}\text { KOEFISIEN } \\
\text { RELIABILITAS }\end{array}$ & $\begin{array}{c}\text { ITEM } \\
\text { PERTANYAAN }\end{array}$ & $\begin{array}{l}\text { KOEFISIEN } \\
\text { KORELASI }\end{array}$ & KETERANGAN \\
\hline \multirow{7}{*}{1} & \multirow{7}{*}{ Pelatihan } & \multirow{7}{*}{0,769} & X.1.1 & 0,701 & Valid \\
\hline & & & X.1.2 & 0,707 & Valid \\
\hline & & & X.1.3 & 0,797 & Valid \\
\hline & & & X.1.4 & 0,689 & Valid \\
\hline & & & X.1.5 & 0,790 & Valid \\
\hline & & & X.1.6 & 0,650 & Valid \\
\hline & & & X.1.7 & 0,539 & Valid \\
\hline \multirow{13}{*}{2} & \multirow{13}{*}{ Motivasi } & \multirow{13}{*}{0,745} & X.2.1 & 0,536 & Valid \\
\hline & & & X.2.2 & 0,606 & Valid \\
\hline & & & X.2.3 & 0,484 & Valid \\
\hline & & & X.2.4 & 0,554 & Valid \\
\hline & & & X.2.5 & 0,789 & Valid \\
\hline & & & X.2.6 & 0,507 & Valid \\
\hline & & & X.2.7 & 0,609 & Valid \\
\hline & & & X.2.8 & 0,594 & Valid \\
\hline & & & X.2.9 & 0,684 & Valid \\
\hline & & & X.2.10 & 0,449 & Valid \\
\hline & & & X.2.11 & 0,594 & Valid \\
\hline & & & X.2.12 & 0,684 & Valid \\
\hline & & & X.2.13 & 0,560 & Valid \\
\hline \multirow{4}{*}{3} & \multirow{4}{*}{ Kinerja } & \multirow{4}{*}{0,769} & Y1 & 0,735 & Valid \\
\hline & & & Y2 & 0,804 & Valid \\
\hline & & & Y3 & 0,659 & Valid \\
\hline & & & Y4 & 0,495 & Valid \\
\hline
\end{tabular}

Berdasarkan data pada tabel 4.1 nilai koefisien korelasi $>0,3$ dan koefisien reliabilitas (alpha crombach) $>0,6$. Jadi seluruh instrumen penelitian adalah valid dan reliable. 


\section{Uji Asumsi Klasik}

1. Uji Normalitas

Tabel 4.2

Hasil Uji Normalitas

One-Sample Kolmogorov-Smirnov Test

\begin{tabular}{|ll|r|}
\hline & & \multicolumn{2}{|c|}{$\begin{array}{c}\text { Unstandardized } \\
\text { Residual }\end{array}$} \\
\hline$N$ & & 37 \\
Normal Parameters ${ }^{\mathrm{a}, \mathrm{b}}$ & Mean &, 0000000 \\
& \multicolumn{1}{|c|}{ Std. } &, 34052849 \\
& Deviation & .097 \\
Most $\quad$ Extreme Absolute & .063 \\
Differences & Positive & -.097 \\
& Negative &, 0932 \\
Kolmogorov-Smirnov Z & .350 \\
\hline Asymp. Sig. (2-tailed) & & \\
\hline
\end{tabular}

a. Test distribution is Normal.

b. Calculated from data.

Hasil uji normalitas pada tabel 4.2 menunjukan nilai kolmogorov-smirnov untuk koefisien asymp sig (2-tailed) sebesar $0,350>$ alpha $=0,05$ yang artinya data penelitian berdistribusi normal.

2. Uji Multikolinearitas Uji multikolinearitas digunakan untuk menunjukan adanya hubungan linier diantara variabelvariabel bebas (independent) dalam model regresi. Jika VIF < 10 dan nilai tolerance $>10 \%$, mengidentifikasikan tidak adanya multikolinearitas (Ghozali, 2011). Hasil uji multikolinieritas dapat dilihat pada tabel 4.7. di bawah ini :

Tabel 4.3

Hasil Uji Multikolinearitas

Menggunakan Nilai Tolerance dan Vif

Coefficients $^{a}$

\begin{tabular}{|c|c|c|c|}
\hline \multirow[b]{2}{*}{ Model } & & \multicolumn{2}{|c|}{ Collinearity Statistics } \\
\hline & & Tolerance & VIF \\
\hline 1 & Motivasi (X2) & .342 & 2.921 \\
\hline & $\begin{array}{l}\text { Pelatihan } \\
\text { (X1) }\end{array}$ & .342 & 2.921 \\
\hline
\end{tabular}

a. Dependent Variable: Kinerja Karyawan (Y)

Hasil penghitungan nilai tolerance pelatihan dan motivasi adalah 0,342> 0,10 yang berarti tidak ada toleransi antara variabel independen dan VIF sebesar 2,921< 10 . Jadi dapat disimpulkan bahwa tidak ada multikolinearitas antar variabel independen dalam model regresi.

3. Uji Heteroskedastisitas 
Uji heteroskedastisitas digunakan untuk menunjukan bahwa variasi variabel tidak sama untuk semua pengamatan. Uji ini bertujuan untuk menguji apakah dalam model regresi terjadi ketidaksamaan varian dari residual satu pengamatan ke pengamatan lainnya. Jika varian dari residual tetap maka disebut homoskedastisitas dan jika berbeda disebut heteroskedastisitas. Model regresi yang baik adalah homoskedastisitas.

Hasil uji heteroskedastisitas dapat diuraikan pada gambar 4.2 di bawah ini

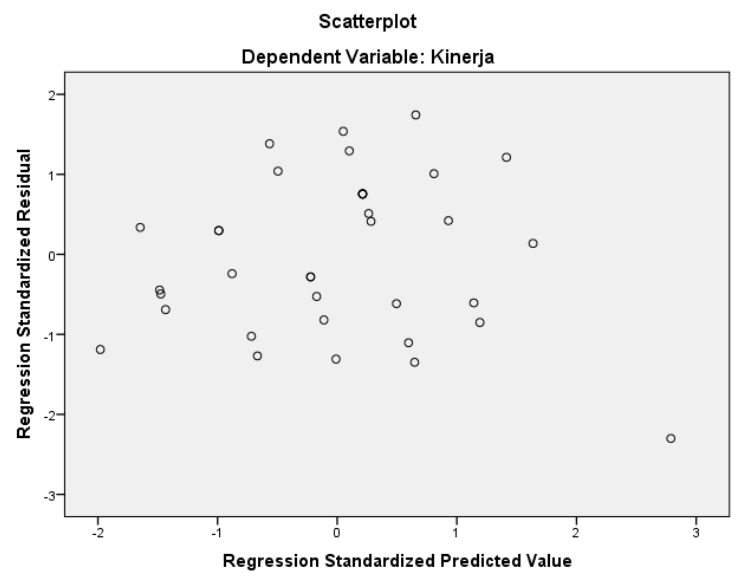

Gambar 4.2

Uji Heteroskedastisitas Dengan Grafik Scatter Plot

Dari grafik scatter plot di atas menunjukan bahwa titik-titik menyebar secara acak serta tersebar, baik di atas maupun di bawah angka 0 pada sumbu Y. Dapat disimpulkan bahwa tidak terjadi heteroskedastisitas pada model regresi, sehingga layak dipergunakan untuk memprediksi kinerja karyawan berdasarkan masukkan pelatihan dan motivasi.

\section{Hasil Analisis Regresi Linier Berganda}

Untuk menjawab masalah dalam penelitian ini dan menguji hipotesis, maka alat analisis statistik yang dipergunakan adalah analisis statistik korelasi (parsial dan berganda), determinasi berganda, regresi berganda, t-test (satu sisi kanan) dan Ftest (ANOVA). Analisis statistik tersebut diolah dengan program SPSS 23. Hasil analisis dari SPSS 23, dapat diuraikan pada tabel 4.4 sebagai berikut: 
Jurnal Manajemen Pelayanan Hotel Akademi Komunitas Manajemen Perhotelan Indonesia (Susila \& Ariantini, halaman 36-51) Vol 1, No 1 Edisi Desember 2017

Tabel 4.4

Hasil Analisis Statistik Pengaruh Pelatihan (x1) dan Motivasi (x2) Terhadap Kinerja Karyawan (y)

\begin{tabular}{|c|c|c|c|c|c|c|c|}
\hline $\begin{array}{l}\text { Variabel } \\
\text { terikat }\end{array}$ & $\begin{array}{l}\text { Variable } \\
\text { bebas }\end{array}$ & $\begin{array}{l}\mathrm{R} \\
\text { (Parsial) }\end{array}$ & $\begin{array}{l}\text { R } \\
\text { (Berganda) }\end{array}$ & B & $\begin{array}{c}\beta \\
\text { (Beta) }\end{array}$ & Thitung & Sig T \\
\hline $\begin{array}{l}\text { Kinerja } \\
\text { Karyawan } \\
\text { (Y) }\end{array}$ & $\begin{array}{l}\text { Pelatihan } \\
\text { (X1) } \\
\text { Motivasi } \\
\text { (X2) }\end{array}$ & $\begin{array}{l}0,828 \\
0,846\end{array}$ & 0,980 & 0,171 & 0.497 & 9.254 & 0,000 \\
\hline \multicolumn{8}{|c|}{$\begin{array}{l}\mathrm{R}^{2}=0,961 \\
\text { Konstanta }=0,867 \\
\text { Persamaan Regresi }: Y=0,867+0,249 X 1+0,171 \mathrm{X} 2 \\
\text { T Tabel }=0,05: 34=1.6909 \\
\mathrm{~F} \text { Hitung }=422.319 \\
\text { Sig. } \mathrm{F}=0.000 \\
\mathrm{~F} \text { Tabel }(0,05: 2: 34)=3.28\end{array}$} \\
\hline
\end{tabular}

Data yang diperoleh dari tabel 4.4 adalah terdapat hubungan yang sangat kuat antara Pelatihan (X1) terhadap Kinerja Karyawan $(\mathrm{Y})$ sebesar 0,828 jika Motivasi (X2) dikendalikan (konstan). Selain itu pada koefisien korelasi antara Motivasi (X2) terhadap Kinerja Karyawan (Y) sebesar 0,846 menunjukan bahwa hubungan yang sangat kuat jika Pelatihan (X1) dikendalikan (konstan). Data lain menunjukan bahwa terdapat hubungan yang sangat kuat antara Pelatihan dan Motivasi terhadap Kinerja Karyawan sebesar 0,980. Hal ini menunjukkan bahwa untuk meningkatkan kinerja karyawan, perusahaan harus tetap mempertahankan kualitas pelatihan dan motivasi kepada karyawan.

1. Analisis Pengaruh Pelatihan (X1) Terhadap Kinerja Karyawan ( $Y$ ) Untuk mengetahui lebih rinci antara pengaruh Pelatihan (X1) terhadap Kinerja Karyawan (Y), maka dianalisis melalui nilai koefisien regresi berganda (b). Koefisien regresi X1(B1) sebesar 0,249 yang memiliki arti bahwa setiap peningkatan Pelatihan (X1) sebesar 1 poin dapat meningkatkan kinerja karyawan sebesar 0,249 poin.

Sehingga dapat disimpulkan bahwa Pelatihan (X1) memiliki pengaruh positif terhadap Kinerja Karyawan (Y). Serta $\mathrm{Ho}=$ tidak terdapat pengaruh positif antara Pelatihan (X1) dengan Kinerja karyawan (Y), serta $\mathrm{Ha}$ terdapat pengaruh positif antara Pelatihan (X1) dengan Kinerja Karyawan ( $\mathrm{Y}$ ) yang menunjukan hasil bahwa koefisien regresi $X 1(B 1) T$ hitung $=8.614>T$ tabel $(0,05: 34)=1.6909$ dan sig $t=0,000(p$ $<0,05)$. Ini menunjukan bahwa Ho ditolak dan menerima $\mathrm{Ha}$, serta berpengaruh signifikan. Ini berarti terdapat pengaruh positif dan signifikan antara Pelatihan (X1) terhadap Kinerja Karyawan (Y). Berdasarkan dari hasil analisis di atas maka, dapat dibuktikan bahwa terjadi pengaruh positif dan signifikan antara Pelatihan terhadap Kinerja karyawan di Maxone Hotel Seminyak-Bali.

2. Analisis Pengaruh Motivasi (X2) Terhadap Kinerja Karyawan (Y) 
Untuk mengetahui lebih rinci antara pengaruh Motivasi (X2) terhadap Kinerja Karyawan (Y), maka dianalisis melalui nilai koefisien regresi berganda (B). Koefisien regresi b2X2 sebesar 0,171 yang memiliki arti bahwa setiap peningkatan Motivasi (X2) sebesar 1 poin dapat meningkatkan kinerja karyawan sebesar 0,171 poin.

Dari data analisis yang diolah dengan SPSS versi 23, dapat diuraikan $\mathrm{X} 2$ (B2) $\mathrm{T}$ hitung $=9.254>\mathrm{T}$ tabel $(0,05$ : $34)=1.609$ dan sig $t=0,000(p<0,05)$. Sehingga dapat disimpulkan bahwa Motivasi (X2) berpengaruh positif dan signifikan terhadap kinerja karyawan (Y). Sehingga $\mathrm{Ho}=$ ditolak dan menerima hipotesis alternative ( $\mathrm{Ha})$. Berdasarkan dari hasil analisis diatas maka, hipotesis yang menyatakan terdapat pengaruh positif dan signifikan antara Motivasi terhadap Kinerja karyawan di Maxone Hotel SeminyakBali dapat dibuktikan dan diterima.

3. Analisis Pengaruh Pelatihan (X1) Dan Motivasi (X2) Terhadap Kinerja Karyawan (Y)

Analisis ini dapat dibuktikan melalui koefisien regresi Pelatihan (b1) dan Motivasi (b2) terhadap Kinerja Karyawan (Y). Bila Pelatihan (X1) dan Motivasi (X2) secara bersama sama dinaikkan sebesar 1 poin, maka Kinerja Karyawan akan meningkat sebesar $0,867(0,249+0,171) \quad$ poin. Ini menunjukkan bahwa variabel Pelatihan (X1) dan Motivasi (X2) berpengaruh positif terhadap Kinerja Karyawan (Y). Hal ini dipertegas dengan pengujian hipotesis dengan menggunakan uji statistik $F$ (ANOVA) dimana $F$ hitung = $422.319>\mathrm{Ftabel}=3.28$, dengan sig $\mathrm{F}=$ $0,000(p<0,05)$. Sehingga dapat diambil suatu kesimpulan bahwa Hipotesis nol $(\mathrm{H} 0)$ ditolak dan menerima hipotesis alternatif $(\mathrm{Ha})$. Secara statistik data yang digunakan dapat membuktikan bahwa Pelatihan (X1) dan
Motivasi (X2) berpengaruh positif dan signifikan terhadap Kinerja Karyawan (Y).

Selain itu kontribusi yang disumbangkan Pelatihan (X1) dan Motivasi (X2) terhadap Kinerja Karyawan (Y) pada Maxone Hotel adalah sebesar 96,1\%, sedangkan sisanya sebesar 3,9\% ditentukan oleh faktor-faktor lain yang tidak dibahas dalam penelitian ini.

Informasi lain yang diperoleh dari hasil analisis di atas bahwa Motivasi (X2), memiliki pengaruh lebih dominan terhadap Kinerja Karyawan (Y) bila dibandingkan dengan Pelatihan (X1). Dimana koefisien regresi $\beta$ (Beta) untuk Motivasi (X2) adalah sebesar 0.534, sedangkan koefisien regresi $\beta$ (Beta) untuk Pelatihan (X1) adalah sebesar 0,497 .

\section{PENUTUP}

Berdasarkan hasil analisis dan pembahasan pada bab sebelumnya, maka dapat ditarik kesimpulan sebagai berikut:

Pelatihan (X1) berpengaruh positif dan signifikan terhadap Kinerja Karyawan (Y) di Maxone Hotel Seminyak-Bali. Sedangkan Motivasi (X2) berpengaruh positif dan signifikan terhadap Kinerja Karyawan (Y) di Maxone Hotel Seminyak-Bali. Sehingga Pelatihan (X1) dan Motivasi (X2) memiliki pengaruh positif dan signifikan terhadap Kinerja Karyawan (Y) di Maxone Hotel Seminyak-Bali.

\section{Saran-Saran}

Dari hasil analisis yang telah dilakukan dalam penelitian ini, maka saran-saran yang dapat diajukan kepada pihak manajemen Maxone Hotel Seminyak-Bali adalah sebagai berikut:
1. Perhatian manajemen terhadap pelatihan dan motivasi terhadap karyawan Maxone Hotel didalam 
upaya mempertahankan dan meningkatkan kinerja karyawan sebaiknya diberikan secara seimbang.

2. Adanya pembaharuan materi pelatihan yang disesuaikan dengan perkembangan pariwisata, sehingga hasil dari pelatihan dapat meningkatkan efesiensi dalam bekerja.

3. Perlu adanya peningkatan motivasi seperti upah, kondisi kerja yang aman dan nyaman yang disertai oleh peningkatan kesadaranakan tugas dan tanggung jawab didalam bekerja.

\section{DAFTAR PUSTAKA}

Arikunto, S. 2013. Prosedur Penelitian: Suatu Pendekatan Praktik. Jakarta: Rineka Cipta.

Danang, Sunyoto. 2013. Metode dan Instrumen Penelitian Ekonomi dan Bisnis Untuk Mahasiswa, Dosen dan Praktisi. Penerbit: Caps Publishing

Dessler, Gary. 2015. Manajemen Sumber Daya Manusia. Jakarta: Salemba Empat.

Ghozali, Imam. 2011. Aplikasi Analisis Multivariate Dengan Program IBM SPSS 17, Cetakan Kelima, Semarang: Badan Penerbit Universitas Diponegoro.

Kaswan. 2012. Manajemen Sumber Daya Manusia untuk Keunggulan Bersaing Yogyakarta: Graha IImu.

Marwansyah. 2014. Manajemen Sumber Daya Manusia. Edisi Kedua. Bandung: Alfabeta

Mangkunegara, Anwar Prabu. 2008. Evaluasi Kinerja SDM. Bandung: Refika Aditama.

Simamora, Henry. 2012. Akuntansi Manajemen, Edisi Ketiga. Riau: Star Gate Publisher.
Sardiman,A.M. 2014. Interaksi dan Motivasi Belajar Mengajar. Jakarta: Rajawali Pers.

Setiadi, Nugroho. 2008. Perilaku Konsumen. Jakarta: Kencana.

Sujarweni, Wiratna. 2015. SPSS Untuk Penelitian. Yogyakarta: Pustaka Baru Press.

Sutrisno, Edy. 2012. Manajemen Sumber Daya Manusia. Jakarta: Kencana.

Sugiyono.2014. Metode Penelitian Bisnis. Bandung: Alfabeta.

Subiyanto,Ibnu.2000. Metodologi penelitian. Yogyakarta: UPP AMPYKPN. 